TEREsa BAL-WoźNIAK

Politechnika Rzeszowska

\title{
Infrastruktura systemu innowacyjnego jako czynnik transformacji struktur przemysłowych*
}

Dokonująca się transformacja struktur przemysłowych polega $\mathrm{w}$ istocie na reindustrializacji (Wieluński 1998; Zioło 2001) i sprowadza się do dostosowywania infrastruktury, zasobów sprzętowych i technologicznych oraz potencjału zatrudnionych do wymagań współczesności, w tym do postępującej serwicyzacji gospodarki. Choć zasada kontynuacji dominuje, to w istocie chodzi o zastępowanie (w sposób inteligentny) rozwiązań przestarzałych, z czasów gospodarki centralnie planowanej i dominacji przemysłu w gospodarce, rozwiązaniami odpowiednimi dla gospodarki rynkowej przebudowywanej w kierunku gospodarki opartej na wiedzy (GOW). Procesy transformacji struktur przemysłowych zbiegają się z wielką przemianą cywilizacyjną, z przechodzeniem do społeczeństwa informacyjnego czy może nawet hiperkomunikacyjnego (Krzysztofek 2007, s. 75), bazującego na wiedzy oraz innowacjach jako narzędziach wykorzystania wiedzy w praktyce.

Prekursor teorii innowacji J. Schumpeter wiązał rozumienie innowacji z wprowadzaniem istotnych zmian w produkcji. Pisał o nowych kombinacjach czynników produkcji, występujących w sposób nieciągły (Schumpeter [1912] 1960, s. 104). W warunkach globalnego kapitalizmu ograniczanie innowacji do sfery produkcji nie znajduje uzasadnienia. Innowacje stanowią podstawę postępu technicznego i rozwoju przemysłów wysokiej techniki, ale równocześnie obejmują sfery: społeczną, polityczną, duchową, zdrowia, konsumpcji oraz wiedzy (entovation). Innowacje we współczesnych warunkach nowego sposobu wytwarzania wiedzy są efektem zbiorowych wysiłków i współdziałania wielu podmiotów. Wymagają systemowego podejścia, które odzwierciedlane jest przez różnego rodzaju systemy innowacyjne: od systemów innowacyjnych poszczególnych firm, poprzez regionalne systemy innowacyjne (Cooke 1998), do krajowego systemu innowacyjnego (Okoń-Horodyńska 2000).

W tych warunkach pytanie o infrastrukturę systemu innowacyjnego wydaje się zasadnie z wielu względów, nie tylko poznawczych czy metodologicznych, ale głównie aplikacyjnych. Stąd teza, że warunkiem osiagania pożądanych dostosowań w procesie transformacji struktur przemysłowych jest odpowiednia infrastruktura. Rozumienie jej jest odmienne od tradycyjnego (Brdulak, red. 2005). Współczesne podejście do infrastruktury odpowiadające GOW, powinno prowadzić poprzez identyfikację i kształtowanie infrastruktury systemu innowacyjnego, to innowacje bowiem umożliwiają czynienie użytku z wiedzy jako dobra powszechnego. Z tym z kolei wiąże się zapotrzebowanie na organizacje nowego typu jako formy zbiorowego uczenia się (organizacje „uczące się”), zdolne nie tylko do rywalizowa-

\footnotetext{
* Praca naukowa finansowana ze środków na naukę w latach 2007-2009 jako projekt badawczy.
} 
nia, ale również do współdziałania. Konsekwencje tych przemian rzutują na struktury przemysłowe, w obrębie pojedynczych przedsiębiorstw oraz ich ugrupowań branżowych i przestrzennych. Prowadzi to do wyłaniania się nowych problemów badawczych, wśród których infrastruktura systemów innowacyjnych wydaje się mieć fundamentalne znaczenie. Celem opracowania jest charakterystyka jej elementów.

\section{ISTOTA INFRASTRUKTURY SYSTEMU INNOWACYJNEGO}

Infrastruktura to urządzenia i instytucje niezbędne do funkcjonowania każdego systemu, jakim może być organizacja (przedsiębiorstwo), gospodarka krajowa, gospodarstwo domowe, społeczeństwo, a nawet gospodarka światowa. W ujęciu potocznym pojęcie infrastruktura jest utożsamiane z infrastrukturą techniczną i sprowadzane do urządzeń w dziedzinie transportu, komunikacji, energetyki, melioracji itp. Wprowadzenie komputerów i wzrost stopnia komputeryzacji mógł wpłynąć na poszerzenie zakresu pojęciowego infrastruktury technicznej. Jednak specyficzny charakter urządzenia, jakim jest komputer, znaczące przemiany w zakresie technologii informacyjnych (w tym informatycznych) oraz zakres zastosowań tych technologii we wszystkich dziedzinach aktywności ludzkiej spowodowały, że w praktyce doszło do wyodrębnienia infrastruktury informacyjnej jako oddzielnej grupy rodzajowej, obok infrastruktury ekonomicznej i infrastruktury społecznej.

Infrastruktura ekonomiczna to ogół instytucji gwarantujących porządek konkurencyjny oraz normujących pozycję i kompetencje podmiotów publicznych (organów samorządowych i państwowych) oraz podmiotów prywatnych w sferze ekonomicznej, tak by nie naruszały one logiki funkcjonowania rynków, a tym samym nie podważały koniecznych do przetrwania na rynku reżimów efektywności mikroekonomicznej (Stiglitz 2004). Infrastrukturę społeczną tworzą zaś instytucje określające reguły funkcjonowania podmiotów w sferze społecznej. W szczególności infrastruktura społeczna obejmuje usługi w zakresie prawa, bezpieczeństwa, oświaty i nauki, kultury, opieki społecznej, służby zdrowia itp.

Tradycyjne traktowanie elementów infrastruktury (obejmujących infrastrukturę techniczną, ekonomiczną, społeczną) nie jest wystarczające dla zrozumienia stopnia zróżnicowania zachowań podmiotów gospodarujących i uchwycenia współzależności występujących $\mathrm{w}$ zintegrowanych procesach innowacyjnych przebiegających $\mathrm{w}$ obecnych warunkach, w których mamy do czynienia z tzw. systematyczną innowacją, tj. z celowym, zarządzanym i specjalnie organizowanym analizowaniem okazji do innowacji, umożliwiającym zachodzenie pożądanych przemian we wszystkich obszarach aktywności organizacji, wewnętrznych i zewnętrznych (Żuber i in. 2006). W ramach posiadanej samodzielności organizacje korzystają z infrastruktury makroekonomicznej, tworząc jednocześnie własne (korporacyjne) rozwiązania infrastrukturalne sprzyjające generowaniu innowacji, i w tym ujęciu infrastrukturę systemu innowacyjnego można traktować jako swoistą nadbudowę. Infrastruktura systemu innowacyjnego przedsiębiorstwa tworzy zatem określone mikrośrodowisko innowacyjne, pozostające pod wpływem jakości infrastruktury systemu społeczno-gospodarczego państwa czy ugrupowania gospodarczego. Wydaje się, że uzasadnione byłoby posługiwanie się pojęciem infrastruktura innowacyjna, co czyni się w dalszej części opracowania, gdyż w istocie określenie infrastruktura ekonomiczna oznacza infrastrukturę systemu ekonomicznego. 
Infrastruktura systemu innowacyjnego obejmuje zespół elementów, które mają charakter elementów aktywnych, czyli takich, że procesy ich kształtowania po osiagnięciu poziomu krytycznego zyskują siłę do samonapędzającego się rozwoju. Wszystkie elementy infrastruktury innowacyjnej odwołują się do warstwy społecznej odzwierciedlanej przez zasoby kapitału intelektualnego. To one ostatecznie przesądzają o skutkach podejmowanych przedsięwzięć transformacyjnych.

Z punktu widzenia skuteczności wspomagania działalności twórczej, należy wyodrębniać i diagnozować sposoby zachowania, w tym sposoby rozwiązywania problemów ujawniania i zwiększania aktywności twórczej oraz problemów w zakresie komunikowania się i współpracy na rzecz innowacji, usankcjonowane normami zwyczajowymi, realizowanymi w określonych ramach prawnych i respektowanymi w danej organizacji. W szczególności należy zwrócić uwagę na takie elementy infrastruktury systemu innowacyjnego, jak przedsiębiorczość, kompetencje, aktywność zespołowa i komunikacja wewnętrzna, rozwiązania organizacyjne wraz ze wsparciem informatycznym oraz sieci powiązań zewnętrznych.

\section{PRZEDSIĘBIORCZOŚĆ W ROLI ELEMENTU INFRASTRUKTURY SYSTEMU INNOWACYJNEGO}

Propozycja postrzegania przedsiębiorczości w roli elementu infrastruktury innowacyjnej, czyli tzw. przedsiębiorczości innowacyjnej (Okoń-Horodyńska 2000), wynika z założenia, że innowacyjność bezwzględnie wymaga przedsiębiorczości, choć wskazywane są również inne powiązania między przedsiębiorczością a innowacyjnością (Moszkowicz 2001). Założenie takie wynika pośrednio z rozumienia istoty przedsiębiorcy, który w ramach procesu „twórczej destrukcji” jest w stanie burzyć istniejące kombinacje czynników wytwórczych dla tworzenia nowych (Schumpeter 1960).

$\mathrm{W}$ warunkach polskich wraz z podjętą transformacją gospodarki w kierunku rynkowym można mówić o odrodzeniu się przedsiębiorczości. Gospodarka rynkowa, oparta na własności prywatnej, wolności wyboru, poziomych powiązaniach partnerskich, liberalnym charakterze prawodawstwa, warunkującego swobodę wejścia na rynek, jest naturalnym środowiskiem przedsiębiorczości (Woźniak 2006). We współczesnej literaturze występuje wiele nowych perspektyw postrzegania przedsiębiorczości, zwłaszcza w zakresie nauk o zarządzaniu. Szczególnie interesujące w kontekście analizowanego problemu wydaje się utożsamianie przedsiębiorczości ze zorganizowanym, społecznym procesem tworzenia i wykorzystywania szans (Bratnicki 2002).

Przedsiębiorczość jest nieodłącznie związana z kreowaniem niepewności wskutek rozważania dużej liczby nowych idei i wariantów decyzyjnych oraz dążeniem do tworzenia i wykorzystywania szans bez względu na zasoby znajdujące się pod bieżącą kontrolą. Przedsiębiorczość opisywana jest przez pryzmat cech osobowych przedsiębiorcy, jego systemu wartości, motywacji i rzeczywistych zachowań. Podkreśla się też umiejętność podejmowania ryzyka związanego z samodzielną działalnością, nowatorstwo, inicjatywę i oryginalność, silną motywację do osiągania wyznaczonych celów przez przedsiębiorców, organizacje przedsiębiorcze bądź uczestników organizacji (np. pracowników).

Przedsiębiorcy rozmyślnie inicjują oraz aktywnie rozwijają przedsięwzięcia służące wykorzystywaniu szans, aby dzięki innowacyjnemu i unikalnemu podejściu do wartości uzyskać przewagę konkurencyjną. W powszechnym rozumieniu przedsiębiorca zakłada własne, 
nowe, małe przedsiębiorstwo. Przedsiębiorczość, rozumiana w ten sposób jako działalność gospodarcza, przekształca zasoby w środki zaspokajające potrzeby lokalne, stanowiąc siłę sprawczą ekspansji małych i średnich przedsiębiorstw (MSP) i będąc utożsamiana z tym sektorem.

Organizacje przedsiębiorcze, dla których przedsiębiorczość jest niezbędnym wymiarem (Bednarczyk 1996, s. 16), traktują ją jako nośnik zdobywania i utrzymywania przewagi konkurencyjnej. Są skłonne do podejmowania ryzyka i eksperymentowania, są zdolne do samodzielnego działania i do innowacji, mają skłonność do identyfikowania i wykorzystywania szans, zanim zrobią to konkurenci, są gotowe do zmian wewnątrzorganizacyjnych mających na celu podwyższenie efektywności funkcjonowania i rozwoju w wysoce konkurencyjnym otoczeniu (Bratnicki 2002, s. 24).

Uczestnicy organizacji, dla których przedsiębiorczość jest elementem infrastruktury systemu innowacyjnego organizacji, reprezentują postawę nakierowaną na podejmowanie inicjatyw, dynamizm w działaniu, kreatywność, a nawet skłonność do podejmowania ryzykownych decyzji i elastyczność w dopasowywaniu się do wymagań rynku. Udostępniają organizacji te swoje zasoby, które decydują ostatecznie o szybkości rozwoju organizacji i jego jakości (Francik 2003, s. 95). Na strukturę tak rozumianej przedsiębiorczości odnoszonej do osób składają się trzy elementy: (1) akt działania, (2) zespół określonych cech, umożliwiających lub ułatwiających podejmowanie określonego rodzaju aktywności, (3) „duch przedsiębiorczości”. W oparciu o te elementy można przyjąć, że przedsiębiorczość to akt działania podejmowany przez osobę posiadającą zespół charakterystycznych cech i obdarzoną „duchem przedsiębiorczości”.

Przedsiębiorczość w roli elementu infrastruktury systemu innowacyjnego organizacji jest pochodną dojrzałości innowacyjnej zatrudnionych i ich zdolności do realizowania swojej podmiotowości w poczuciu wolności, możliwości samostanowienia i ponoszenia odpowiedzialności. Ukształtowanie się przedsiębiorczości w takim charakterze wymaga od kompetentnych i stale doskonalących się pracowników wyzwalania „ducha przedsiębiorczości” i utrzymywania „twórczego napięcia”, prowadzącego do kolejnych „aktów działania": (1) dostrzegania sytuacji innowacyjnych (wykrywania szans), (2) kojarzenia obserwowanych zjawisk z posiadaną wiedzą i poznanymi wzorcami, (3) odczuwania powinności (możliwości i konieczności) zadziałania oraz (4) zdobywania dostępu do zasobów i uruchamiania ich. Wyróżnione komponenty składają się na zachowania organizacyjne, które dobrze charakteryzuje formuła: chcieć - umieć - odczuwać powinność - potrafić.

Prezentacja przedsiębiorczości jako elementu infrastruktury innowacyjnej wiąże się ze sposobem interpretowania innowacji i innowacyjności, w kontekście kształtowania konkurencyjności organizacji (Adamkiewicz-Drwiłło, red. 2007). Innowacyjność może przejawiać się na trzech poziomach: strategicznym, taktycznym i operacyjnym. Odpowiada to postrzeganiu innowacyjności w perspektywie krótko-, średnio- i długookresowej, co jest powiązane $\mathrm{z}$ różnymi rodzajami innowacji. Innowacje produktowe, oparte na najnowszych technologiach, z pewnością mają charakter strategiczny. Mają ponadto moc generowania innowacji pochodnych o charakterze operacyjnym i taktycznym. Wymagają sprzyjającego klimatu organizacyjnego i proinnowacyjnej kultury organizacyjnej przedsiębiorstwa. Pojawienie się oryginalnej innowacji produktowej stanowi dla organizacji zdarzenie gospodarcze o przełomowym znaczeniu. W rzeczywistości jednak trwały trend rozwojowy organizacji podtrzymywany jest dzięki udoskonaleniom i modernizacjom w zakresie produktów, procesów technologicznych oraz w zakresie organizacji i zarządzania, będącym efektem proinnowa- 
cyjnych postaw i zachowań innowacyjnych opartych na przedsiębiorczości w perspektywie krótkookresowej.

W praktyce te trzy wymiary innowacyjności przenikają się wzajemnie i każdy z pracowników organizacji doświadcza tego, choć w zróżnicowanym stopniu. W każdym przypadku chodzi o zdolności urzeczywistniania nowych rozwiązań przynoszących określone korzyści, ale w miarę przechodzenia od stanowisk wykonawczych do stanowisk usytuowanych na wyższych szczeblach struktury organizacyjnej występuje konieczność, a jednocześnie wzrasta trudność godzenia wymagań wynikających z celów bieżących i rozwojowych. Jeżeli jednak proces kształtowania dojrzałości innowacyjnej w przedsiębiorstwie wszedł w stadium zaawansowane, co znajduje odzwierciedlenie w kulturze organizacyjnej premiującej zachowania innowacyjne, to godzenie celów bieżących i rozwojowych ma szansę przebiegać sprawnie.

Z przedstawionych rozważań wynika, że źródeł dynamizmu systemu innowacyjnego organizacji, umożliwiającego budowanie i rozwój przewagi konkurencyjnej, należy poszukiwać w stopniu rozwoju przedsiębiorczości, na który zasadniczy wpływ wywierają kompetencje i kreatywność ich uczestników.

\section{KOMPETENCJE I KREATYWNOŚĆ UCZESTNIKÓW ORGANIZACJI}

Z punktu widzenia infrastruktury systemu innowacyjnego przedsiębiorstwa należy rozstrzygnąć dylemat, czy polityka personalna przedsiębiorstwa powinna być ukierunkowana na zarządzanie kompetencjami, czy ciagle jeszcze na zarządzanie zasobami ludzkimi, tak jak czyniono to dotychczas, kiedy problematyka kompetencji była tylko jednym z obszarów analitycznych (Pocztowski 2006). Rozstrzygnięcie tego dylematu wymaga odpowiedzi na pytanie: na ile nabór, oceny, awanse, szkolenia i systemy motywacyjne organizacji ukierunkowane są na ustawiczne zdobywanie wiedzy, doskonalenie umiejętności, poszanowanie wartości, rozwijanie proefektywnościowych i proinnowacyjnych postaw.

Wyróżnione elementy: wiedza, umiejętności, wartości i postawy, składają się na powszechnie akceptowany czteroelementowy model kompetencji indywidualnych. Główni badacze kompetencji L. Spencer i S. Spencer zaproponowali strukturę bardziej rozbudowaną, obejmującą obok wiedzy, umiejętności i wartości również standardy, motywy, etykę pracy, entuzjazm, własny wizerunek (Spencer, Spencer 1993).

Wiążąc kompetencje indywidualne z możliwościami osobistej samorealizacji i uwzględniając rozłożenie akcentów między wymienione cztery elementy, można zastosować dwojaką interpretację, zgodnie $\mathrm{z}$ którą kompetencje indywidualne to:

- wyuczone umiejętności oparte na naturalnych zdolnościach, które ujawniają się w zachowaniach przy wykonywaniu określonych zadań poprzez wykazywanie sprawności realizacyjnych: poznawczych, motywacyjnych, technicznych, społecznych, komunikacyjnych i innych (zależnie od konkretnej profesji);

- zespół ocen i oczekiwań człowieka co do jego zdolności adaptacyjnych w konkretnych warunkach, które wpływają na potencjalne możliwości wykorzystania określonych jego zdolności.

O wykorzystywaniu potencjału kompetencji indywidualnych decydują nie tylko inwestycje w kapitał ludzki (wiedza i umiejętności). Zależą one bardziej od uznawanych i po- 
dzielanych wartości (hierarchia wartości, wartości dominujące, wzory zachowań, podstawy autorytetu, motywatory) oraz określonych postaw (nastawienie pesymistyczne lub optymistyczne, umiejscowienie kontroli, postrzeganie przyszłości, stosunek do otoczenia, podstawy sukcesu).

Najczęściej podnoszony jest pierwszy aspekt rozumienia kompetencji i ma on wyraźnie określony charakter działaniowy (sprawnościowy). Jest to podejście bardzo użyteczne w praktyce, łatwiejsze do konceptualizacji, weryfikacji, w tym pomiaru i monitorowania kompetencji zawodowych. Akcentowanie wiedzy i umiejętności, jako łatwiejszych do stwierdzenia niż wartości i postawy, bardziej też koresponduje z możliwościami kształtowania tych składowych kompetencji w ramach szkolnictwa obowiązkowego i w ramach szkoleń. Literatura poświęcona kompetencjom zawiera długie listy kompetencji menedżerskich. Rozwój kompetencji jest procesem ciąłym, w którym można wyodrębnić kolejne etapy, od całkowitego braku umiejętności aż do doskonałości w opanowaniu danej umiejętności (co dobrze ilustruje przykład uczenia się jazdy na rowerze).

Drugi aspekt indywidualnych kompetencji, który decyduje o zdolnościach adaptacyjnych jednostki, jest bardziej przydatny do rozumienia kompetencji innowacyjnych, które stanowią specyficzną kombinację wiedzy, umiejętności, wartości i postaw, wyrastającą na bazie posiadanej już wiedzy, doświadczenia i wyznawanych wartości. Pomimo uniwersalnego charakteru, znacznie różnią się treścią w przypadku poszczególnych osób, zależnie od odgrywanej przez nie roli (społecznej, zawodowej), a także pozycji w strukturze organizacyjnej. Wydaje się jednak, że wskazany już wcześniej proces kształtowania się dojrzałości innowacyjnej człowieka w powiązaniu z jego podmiotowością dobrze oddaje sens kompetencji jako elementu infrastruktury systemu innowacyjnego.

Nabywanie kompetencji w szerokim tego słowa znaczeniu wymaga takiego rodzaju uczenia się, o którym P. Senge pisze, że jest głębokim uczeniem się, sięga do sedna tego, co znaczy być człowiekiem; dzięki takiemu uczeniu się przeobrażamy samych siebie; jesteśmy w stanie zrobić coś, czego inaczej nie bylibyśmy w stanie zrobić; postrzegamy świat i nasze relacje z nim, rozwijamy nasze możliwości twórcze i stajemy się częścią twórczych procesów życia (Senge 1998, s. 26). Zmiana podejścia do sposobu uczenia się jest konsekwencją rozwoju sektorów wysokiej techniki, w których zmniejsza się udział pracy o charakterze substancjalnym (niekreatywnym) na rzecz procesów kreatywnych.

Kreatywność występuje na listach kompetencji menedżerskich, ale wymaga odrębnego opisu, gdyż dzięki niej inne kompetencje stają się aktywne lub bardziej dynamiczne. Kreatywność daje się mierzyć rezultatem działalności jednostki, zespołu i organizacji. Pośrednio wszyscy możemy przesądzać o pojawieniu się twórczej aktywności przez preferowanie kreatywnych zachowań i właściwości ludzi oraz ich wytworów/produktów (Tokarz 2005, s. 11).

W procesie kształtowania kreatywności i kompetencji w ogóle zasadniczą rolę ma do odegrania edukacja, która jednak w ocenie wielu gremiów i indywidualnych stanowisk nie spełnia oczekiwań. Obecne kształcenie pozwala wprawdzie na „zdobywanie pewnych kompetencji, ale nie dość przemienia osobę od wewnątrz. Istnieje bowiem różnica między umieć coś robić, a umieć być świadomie w odpowiedni sposób, np. bez uruchamiania osądu czy negatywnych emocji, zachowując jasny, spokojny umysł" (Iwicka 2005, s. 76). Źródeł wzmocnień w zakresie kompetencji i kreatywności uczestników organizacji można poszukiwać w tworzeniu warunków do ujawniania się aktywności zespołowej i usprawniania komunikacji wewnętrznej. 


\section{AKTYWNOŚĆ ZESPOŁOWA I KOMUNIKACJA WEWNĘTRZNA}

Wiele przesłanek wpływa na włączenie aktywności zespołowej i komunikacji wewnętrznej do infrastruktury systemu innowacyjnego organizacji, ale szczególnie ważne są dwie: możliwość wzmocnienia kreatywności oraz uaktywnienie procesu dzielenia się wiedzą.

Wzmocnienie kreatywności w przypadku podjęcia pracy zespołowej jest możliwe, gdyż zespół potrafi rozwinąć niezwykłą zdolność skoordynowanych działań i porozumiewania się na „niezwykłym poziomie”. Poziom ten wynika z odpowiedniego ukierunkowania ludzi, którzy potrzebni są sobie nawzajem do działania. Jest to stan, w którym zespół ludzi funkcjonuje jak jedna całość. Źródła sukcesów pracy zespołowej tkwią więc w harmonizacji i sumowaniu się energii członków zespołu.

Uaktywnienie procesu dzielenia się wiedzą wynika z kolei z dominującej formy komunikowania się zespołu - dialogu zamiast dyskusji. Właśnie w czasie dialogu zespół otwiera się na „zjawisko przepływu wyższej inteligencji” (Senge 1998, s. 237). W dialogu ludzie osiągają poziom rozumienia problemów, którego nie można osiagnnąć indywidualnie.

Podjęcie przez organizację trudu zbudowania systemu prac zespołowych i komunikacji wewnętrznej świadczy o zrozumieniu istoty procesów tworzenia rozwiązań kreatywnych, dążeniu do spożytkowania wiedzy i energii zatrudnionych pracowników czy pozyskiwaniu pełnego zaangażowania.

Dostrzeganie korzyści zespołowej aktywności i świadomości, że pojedyncze osoby nie mogą osiaggnąć stanu możliwego do osiągnięcia w działaniu w zespole, ma szansę stać się dominującym podejściem, chociażby ze względu na efekty pracy zespołowej, społeczny charakter procesu kreowania innowacji, kształtowanie się stosunków międzyludzkich i rozwijanie umiejętności współpracy. Dotyczy to głównie zespołów powstających spontanicznie, w reakcji na sygnały płynące $\mathrm{z}$ otoczenia, w których mechanizm sterujący może mieć charakter heterarchii jako struktury, w której nie ma stałego ośrodka władzy. Władzę posiada ten członek zespołu, który dysponuje najpełniejszą wiedzą. Przy takim funkcjonowaniu zespołów najczęściej mamy do czynienia ze sprawnymi kanałami wewnętrznej komunikacji. Miarą sprawności komunikacji wewnętrznej jest rozumienie przez pracowników celów i strategii firmy, gotowość szybkiej reakcji na zmiany w otoczeniu rynkowym, wykazywanie aktywności w reakcji na oczekiwania klientów i działania konkurentów, okazywanie lojalności i zaufania do firmy. System prac zespołowych i komunikacji wewnętrznej może zostać umiejętne połączony ze wsparciem organizacyjnym i informatycznym działań innowacyjnych.

\section{WSPARCIE ORGANIZACYJNE I INFORMATYCZNE DZIAŁAŃ INNOWACYJNYCH}

Współczesne działania innowacyjne podejmowane w ramach prac zespołowych moga zyskać wsparcie dzięki wprowadzeniu hipertekstowej struktury organizacyjnej. W polskich przedsiębiorstwach nadal mamy do czynienia ze strukturami biurokratycznymi. Jak podkreślała F. Hesselbein, ,[...] stara hierarchia, która wpisała ludzi i ich funkcje w kwadraty i prostokąty tworzące niepodważalną strukturę organizacyjną, funkcjonowała całkiem nieźle. Stworzyła nawet powszechnie znaną piramidę z dyrektorem naczelnym spoglądającym z jej szczytu na dół i pracownikami patrzącymi do góry" (Hesselbein 1998, s. 101). 
W czasach powszechnej niepewności i gwałtownych zmian, we wszystkich organizacjach trzech sektorów - państwowego, prywatnego i społecznego - ujawnia się niezadowolenie z funkcjonowania podstawowych instytucji. Organizacje są ciagle bardziej dostosowane do zadań i funkcji gospodarki i społeczeństwa przemysłowego niż do wyzwań GOW i społeczeństwa informacyjnego. W organizacjach gospodarczych są podejmowane działania na rzecz wprowadzania struktur organicznych, wśród których struktura zadaniowa zyskała największą popularność. Powoływane do rozwiązania konkretnego problemu zespoły zadaniowe pracują w zakreślonych czasowo ramach i koncentrują się na ściśle określonym celu. Przynosi to dobre rezultaty i sprawdza się w niektórych dziedzinach działalności innowacyjnej, np. w dziedzinie rozwoju nowego produktu. Jest to przykład elastycznej struktury organizacyjnej lepiej dostosowanej do cech współczesnego środowiska funkcjonowania przedsiębiorstw niż struktury tradycyjne (liniowa, funkcjonalna). Struktura zadaniowa niezbyt jednak odpowiada zasadom modernizacji refleksyjnej, niezbędnej dla rozwoju GOW, o zwiększonych wymaganiach w zakresie systematycznego i rozległego upowszechniania wiedzy w organizacji.

Właściwym rozwiązaniem byłoby wprowadzenie struktury zbudowanej na zasadzie połączenia sprawności biurokratycznej z elastycznością struktury zadaniowej. Funkcje tę zdaje się spełniać hipertekstowa struktura organizacyjna (Nonaka, Takeuchi 2000), której nazwa pochodzi od rozwiniętego początkowo w informatyce hipertekstu, pozwalającego użytkownikowi na dostęp do wielu warstw tekstu. Wprowadzenie hipertekstowej struktury organizacyjnej może odbywać się w sposób stopniowy. Przebieg tego procesu może być łatwiejszy w tych przedsiębiorstwach, które wykorzystują rozwiązania macierzowej struktury organizacyjnej. W strukturze macierzowej pracownik jest równocześnie członkiem dwóch komórek organizacyjnych, co zmniejsza możliwości koncentracji sił i środków na rozwiązaniu określonego problemu. W strukturze hipertekstowej w danym momencie pracownik należy tylko do jednej warstwy i jednego kontekstu. Pełne dostosowanie kompetencji do konkretnych potrzeb organizacji wzmacniane jest przez możliwości zmieniania kontekstów przez pracowników. Realizowanie zadań oparte jest na zasadach pracy projektowej. Nadrzędną zasadą jest ustalanie nieprzekraczalnych terminów projektów.

Źródła wsparcia organizacyjnego związane ze strukturą hipertekstową tkwią w takich elementach, jak uznanie „dzielenia się wiedzą” za podstawowy wymóg i sprzyjanie temu poprzez usuwanie barier mentalnych i fizycznych, spłaszczona struktura umożliwiająca aktywne dzielenie się wiedzą i bezpośrednie interakcje pracowników, liczne mechanizmy aktywnego przepływu wiedzy i rotacji stanowisk pracy, zapewnianie pełnego dostępu do informacji z szerokim wykorzystaniem technologii informatycznej. Technologia informatyczna bowiem to nie tylko komputery i ich oprogramowanie, ale także wiedza typu knowhow (Łobejko 2005). Część z tej wiedzy ma charakter idiosynkretyczny. Jest to swoista wiedza jednostkowa, kreowana przez człowieka samodzielnie i dostęp do niej jest utrudniony. By wiedza w ogóle, a wiedza idiosynkretyczna w szczególności, choć w części stała się wiedzą korporacyjną, czyli przekształciła się w unikatowy zasób danego przedsiębiorstwa, potrzebuje odpowiedniej infrastruktury informacyjnej (Pakulska 2005).

Z podnoszonego przez B. Stefanowicza aksjomatu egzystencjalnego wynika, że system informacyjny organizacji powstaje spontanicznie wraz z powzięciem zamysłu w sprawie uruchomienia określonej działalności gospodarczej i w sprawie zorganizowania firmy (Stefanowicz 2007). Jego pierwotna wersja wymaga udoskonaleń i może być ukierunkowana na stosowanie technologii informatycznych. Stopień informatycznego wsparcia działań 
innowacyjnych zależy od posiadanego sprzętu informatycznego, doświadczeń w zakresie umiejętności jego wykorzystywania do usprawniania procesów informacyjnych oraz znajomości technik zarządzania innowacjami. Znaczenie wsparcia informatycznego jest nie do przecenienia w warunkach wzrastającej roli współpracy w rozwoju innowacyjności, głównie w kontekście tworzenia sieci powiązań zewnętrznych, w tym szczególnie angażowania klientów (prosumentów) i naukowców spoza firmy, a także konkurentów do identyfikowania i rozwijania idei nowych produktów.

\section{SIECI POWIĄZAŃ ZEWNĘTRZNYCH}

Procesy innowacyjne rzadko mieściły się w ramach jednej organizacji. Tym bardziej we współczesnych warunkach funkcjonowania organizacji system zarządzania innowacjami wymaga oparcia na sieci powiązań zewnętrznych. Wśród przesłanek tego stanu dwie wydają się mieć fundamentalny charakter: zintegrowany przebieg cykli innowacyjnych oraz przewaga popytowych źródeł innowacji.

Realne procesy innowacyjne odbiegają współcześnie od modeli liniowych, w których przechodzenie od badań podstawowych i stosowanych (B), poprzez prace rozwojowe (R), do wdrożenia nowego rozwiązania (W) i jego upowszechnienia (U) - mogło być przewidywane czy mogło mieć planowy charakter. Na proces odchodzenia od modeli liniowych i wzrost znaczenia zintegrowanych modeli innowacyjnych zdecydowany wpływ wywierają różnorodne przesłanki, takie jak tempo rozwoju wiedzy jako podstawy innowacji, nowy sposób wytwarzania wiedzy oparty na społecznym procesie interakcji i współpracy; wysoka niepewność wyników podejmowanych działań, wzmagana przez turbulentność otoczenia, coraz większa złożoność procesu innowacyjnego, wyrażająca się koniecznością bieżącego uwzględniania wpływów otoczenia niezależnie od stopnia zaawansowania prac nad nowym rozwiązaniem, możliwością pojawiania się nagle nowych odkryć i wielokrotnymi powrotami do etapów wcześniejszych.

W tych warunkach sieci powiązań zewnętrznych tworzą infrastrukturę otoczenia w tradycyjnym tego słowa znaczeniu (w postaci ustawodawstwa, systemu edukacji, systemu finansowego, systemu komunikacji), na którą przedsiębiorstwo ma ograniczone możliwości oddziaływania. Powstaje też infrastruktura wspótpracy oparta na relacjach łączących poszczególnych uczestników procesu gospodarowania zainteresowanych współdziałaniem na rzecz innowacji oraz infrastruktura interakcji przebiegających między partnerami, którzy dla realizacji celów biznesowych z wykorzystaniem rozwiązań innowacyjnych utworzyli formalną strukturę, np. w postaci klastra.

Identyfikację i diagnozowanie infrastruktury współpracy i infrastruktury interakcji można oprzeć na koncepcji interesariuszy (stakeholders), dla określenia i podkreślenia wielości podmiotów funkcjonujących w otoczeniu przedsiębiorstwa, oraz na koncepcji sieci, jako sieciowej formy koordynacji działań, opartej na specyficznej logice sieci.

Lista interesariuszy, których zachowania mogą mieć wpływ na działalność innowacyjną przedsiębiorstwa, jest długa i znajdują się na niej m.in.:

- klienci, o tym większej sile oddziaływania, im bardziej konkretnie wyrażają swoje oczekiwania (sygnalizują zmiany upodobań czy ujawniają reakcje na nowy produkt), 
- dostawcy środków i przedmiotów pracy, inicjujący procesy innowacyjne u odbiorcy,

- jednostki transferu wiedzy i technologii,

- instytucje prawa - sądy, kancelarie i prawnicy, prowadzący obsługę prawną oraz udzielający konsultacji i świadczący usługi doradztwa,

- jednostki badawcze i normalizacyjne, uczelnie wyższe, stowarzyszenia branżowe,

- instytucje finansowe, np. banki czy venture capital jako potencjalni „dostarczyciele" kapitału,

- inne przedsiębiorstwa, stanowiące wzorzec w zakresie korzystnych rozwiązań i podstawę benchmarkingu,

- konkurenci, w ramach aliansów strategicznych (np. konsorcjów) tworzonych dla rozwiązywania problemów, przykładowo wspólnego z innymi firmami tworzenia idei nowego produktu,

- indywidualni lub zespołowi eksperci i konsultanci, inspirujący własnych twórców do działań innowacyjnych,

- władze lokalne, regionalne lub państwowe, które są w stanie tworzyć sprzyjające środowisko instytucjonalne dla działalności innowacyjnej i z którymi przedsiębiorstwo współpracuje w realizacji inicjatyw w zakresie ochrony środowiska, lokalnej infrastruktury technicznej i społecznej, sponsoringu,

- lokalna społeczność, np. odczuwająca niedogodności związane z funkcjonowaniem przedsiębiorstwa lub korzystająca ze sponsoringu.

Źródłem aktywności wszystkich tych grup jest zainteresowanie wynikami firmy i podejmowanie działań dla wywarcia presji, by firma swoim funkcjonowaniem sprzyjała osiąganiu ich celów.

Koncepcja sieci przewiduje celowe utworzenie struktury koordynacji działań i realizowanie działalności innowacyjnej na zasadzie interakcji między partnerami - uczestnikami sieci. Sieci w roli struktury koordynacji regulującej zachowania organizacyjne zespołów i jednostek otwierają perspektywy pomnażania wartości dzięki logice funkcjonowania łączącej korzyść jednostkową z korzyścią ogółu uczestników sieci.

Jako składnik ładu spontanicznego, sieci nie są produktem władzy centralnej, lecz efektem interakcji jednostek funkcjonujących w systemie zdecentralizowanym. Podstawą rozumienia sieci w ogóle jest zrozumienie istoty sieci społecznej, która jest moralną relacją zaufania w grupie jednostek, które podzielają normy nieformalne lub wartości wykraczające poza te, które okazują się niezbędne do przeprowadzania zwykłych transakcji rynkowych (Fukuyama 2000).

Szczególnym przypadkiem sieci są klastry (regional clusters), stanowiące geograficzne skupiska wzajemnie powiązanych firm, wyspecjalizowanych dostawców, jednostek świadczących usługi, firm działających w pokrewnych sektorach i związanych z nimi instytucji (na przykład uniwersytetów, jednostek normalizacyjnych i stowarzyszeń branżowych) w poszczególnych dziedzinach, konkurujących między sobą, ale także współpracujących (Porter 2001). Są one wspierane przez sieć instytucji z sektora prywatnego i publicznego, promujących kolektywne uczenie się oraz procesy powstawania i dyfuzji innowacji (Bojar, red. 2006). Klastry mogą stanowić strukturę w pełni dostosowaną do tworzenia i upowszechniania innowacji. W strukturach klastrowych powstają fizyczne warunki do przebiegu procesów innowacyjnych w pełnych zintegrowanych cyklach, w warunkach wzajemnego i równoległego oddziaływania wszystkich uczestników tych procesów: realizatorów badań, prac rozwojowych, prac wdrożeniowych i działań rynkowych (marketingowych, konsumenckich). 
Klaster funkcjonuje na wzór organizacji inteligentnych, w których zarządzanie przestaje być działaniem zewnętrznym, co sprzyja innowacyjnym zachowaniom: uczestników sieci w zakresie osiagania ich celów biznesowych; jednostek zaplecza naukowo-badawczego (szkoły wyższe, instytuty badawczo-rozwojowe) w zakresie techniki, technologii i nowych rozwiązań organizacyjnych; placówek dydaktycznych w zakresie edukacji i organizowania szkoleń; jednostek okołobiznesowych w zakresie finansowania, doradzania i upowszechniania innowacji; jednostek władzy w zakresie tworzenia infrastruktury społeczno-technicznoekonomicznej. Każdy z uczestników wymienionych grup jako podmiot samodzielny w świetle prawa funkcjonuje w zakresie wynikającym z jego celów statutowych. Od stopnia rozwoju kapitału społecznego jako podstawy współpracy zależy obszar wspólnej aktywności podejmowanej dla dobra wspólnego. By jednak klaster mógł ,przyciagać” kapitał, pracowników i strumienie wiedzy, musi posiadać ,atrakcyjność zewnętrzną” związaną z jego zamierzeniem strategicznym oraz wewnętrzną dynamikę, możliwą do podtrzymania i rozwoju dzięki innowacyjności odnoszonej do ludzi go tworzących, traktowanej jako jeden z wymiarów ich podmiotowości, a bazującej na odpowiednim poziomie kompetencji innowacyjnych.

W sieciowych strukturach koordynacji ma szansę być realizowany wymóg kojarzenia rywalizacji i współdziałania we współczesnych procesach gospodarczych wymagających innowacyjności. W strukturach tych, dzięki występowaniu kapitału społecznego, egoistyczne zachowania jednostek mogą zostać podporządkowane wspólnym interesom zbiorowości.

Idea tworzenia klastrów, $\mathrm{z}$ powodzeniem realizowana $\mathrm{w}$ wielu rozwiniętych krajach świata, napotyka w warunkach polskich na liczne bariery, które są pochodną wielu niedostatków polskiego systemu innowacji. Poziom dofinansowania ze środków budżetowych nakładów na $\mathrm{B}+\mathrm{R}$ w okresie transformacji nie zwiększył się, pomimo oficjalnych deklaracji i przystąpienia Polski do realizacji Strategii Lizbońskiej. Jednostki naukowo-badawcze pracują nad rozwiązaniami, które niekoniecznie trafiają $\mathrm{w}$ najpilniejsze potrzeby przedsiębiorców, a przedsiębiorcom brakuje świadomości i czasem wiary w to, że nauka jest w stanie rozwiązać ich problemy technologiczne czy w sferze zarządzania. Zaangażowanie przedsiębiorców w finansowanie $\mathrm{B}+\mathrm{R}$ jest ciągle znacznie poniżej poziomu rejestrowanego w krajach rozwiniętych.

\section{WNIOSKI POD ADRESEM TRANSFORMACJI STRUKTUR PRZEMYSŁOWYCH}

O ile transformacja systemu gospodarczego w Polsce, określana jako szokowa, miała wysoką dynamikę, o tyle transformacja struktur przemysłowych dostosowująca je do wymagań GOW i wzrostu udziału w gospodarce usług, w tym szczególnie usług nowego typu, daleka jest od oczekiwań. Ocena nie ulega zmianie nawet wówczas, gdy uwzględni się fakt, że transformacja struktur przemysłowych jest procesem o kumulatywnym charakterze, odznaczającym się stopniowym narastaniem zmian, których dynamika może ulec istotnemu zwiększeniu dopiero po osiagnięciu pewnego krytycznego ich poziomu.

Nasuwa się pytanie, czy możliwe jest dynamizowanie przemian strukturalnych? Czynniki egzogeniczne, szczególnie te związane z procesami postępującej globalizacji, odgrywają zasadniczą rolę, ale w odniesieniu do krajów i regionów rozwiniętych gospodarczo, choć należy docenić ich oddziaływanie także na kraje i regiony mniej rozwinięte.

Zwrócenie uwagi na czynniki endogeniczne pozwala także na spojrzenie na procesy transformacji i ich dynamikę z poziomu lokalnego, mikroekonomicznego. W procesach 
restrukturyzacji nie występuje zjawisko prostego przekładania się efektów jednej skali na efekty widoczne w innej skali. Jednak z logiki rozwojowej wynika konieczność sięgnięcia do źródeł aktywności jednostek - ludzi odgrywających różne role społeczne i zawodowe, których postawy i zachowania (w tym zwłaszcza proinnowacyjne zachowania organizacyjne w środowisku pracy), mogą zapobiegać ewentualnym negatywnym skutkom makroekonomicznych przemian. Współcześnie bardziej jednak chodzi o podkreślenie możliwości włączenia kapitału ludzkiego, a szerzej - kapitału intelektualnego, w kształtowanie takiej infrastruktury systemów innowacyjnych organizacji (biznesowych, administracyjnych, edukacyjnych, naukowo-badawczych, okołobiznesowych), by ludzie chcieli, umieli, odczuwali powinność i potrafili korzystać z wiedzy dla urzeczywistniania innowacji zmieniających istniejące struktury w takie, które odpowiadają współczesnym wymaganiom.

$\mathrm{Na}$ charakteryzowaną infrastrukturę innowacyjną składają się elementy aktywne, których kształtowanie przebiegać może w sposób samoistny, pod warunkiem jednak osiągnięcia poziomu krytycznego. Charakter zasobów infrastruktury innowacyjnej mógłby sugerować, że można je kształtować w sposób bezinwestycyjny. Choć faktycznie mają w większości charakter niematerialny, to nie znaczy, że niepotrzebne było zaangażowanie środków rzeczowych czy finansowych. Dzisiejsze zasoby niezbędne do kształtowania elementów infrastruktury systemów innowacyjnych stanowią produkt długotrwałego rozwoju i efekt inwestowania w kapitał ludzki: w ochronę zdrowia, w zdrowy tryb życia, formalne kształcenie, dokształcanie w czasie pracy i poza nią, dostępność informacji itp. (Domański 1993, s. 19-26). Zmiany strukturalne, jak podkreśla Okoń-Horodyńska (2000), nie są osiagalne przez prosty transfer innowacji (np. nowej technologii) pomiędzy różnymi krajami. Rzeczywiste źródła restrukturyzacji mają korzenie w kompetencjach (wiedzy, umiejętnościach, wartościach, postawach) i kreatywności, wzmacnianych poprzez aktywność zespołową i sprawną komunikację wewnętrzną, wspieranych od strony organizacyjnej i informatycznej, znajdujących potwierdzenie w przedsiębiorczości innowacyjnej, podejmowanej coraz częściej w ramach struktur sieciowych.

W kontekście powyższego ważne jest stwierdzenie, że infrastruktura systemu innowacyjnego organizacji będzie zależeć od sprawności najsłabszego jej elementu. Ponieważ podejście systemowe wyklucza redukcję systemu do pojedynczych jego elementów, konieczne jest zabieganie o spójność rozwiązań jako podstawowego mechanizmu zabezpieczania celów, w tym przypadku celów związanych z transformacją struktur przemysłowych.

\section{Literatura}

Adamkiewicz-Drwiłło H., red., 2007, Uwarunkowania rozwoju przedsiębiorczości, PWN, Warszawa Bednarczyk M., 1996, Otoczenie i przedsiębiorczość w zarzqdzaniu strategicznym organizacja gospodarczq, Wyd. AE, Kraków

Bratnicki M., 2002, Przedsiębiorczość i przedsiębiorcy wspótczesnych organizacji, Wyd. AE, Katowice Brdulak J., red., 2005, Rozwój elementów infrastruktury życia społeczno-gospodarczego, SGH, Warszawa Bojar E., red., 2006, Klastry jako narzędzia lokalnego i regionalnego rozwoju gospodarczego, PL, Lublin Cooke Ph., red., 1998, Regional Innovation Systems: Designing for the Future - REGIS, Reports, Commission European, Brussels

Domański R.S., 1993, Kapitat ludzki i wzrost gospodarczy, PWN, Warszawa

Francik A., 2003, Sterowanie procesami innowacyjnymi w organizacji, Wyd. AE, Kraków 
Fukuyama F., 2000, Wielki wstrzqs. Natura ludzka a odbudowa porzqdku społecznego, Politeja, Warszawa

Hesselbein F., 1998, Organizacja okrężna, [w:] Organizacja przyszłości, red. F. Hesselbein, M. Goldsmith, R. Beckhard, Business Press, Warszawa

Iwicka M., 2005, O potrzebie nowej filozofii edukacyjnej, „Edukacja Ekonomistów i Menedżerów”, nr 2

Łobejko S., 2005, Systemy informacyjne w zarzadzaniu wiedza i innowacja w przedsiębiorstwie, SGH, Warszawa

Malara Z., 2007, Przedsiębiorstwo w globalnej gospodarce. Wyzwania wspótczesności, PWN, Warszawa

Moszkowicz K., 2001, Procesy innowacyjne w polskim przemyśle, Wyd. AE, Wrocław

Nonaka I., Tateuchi H., 2000, Kreowanie wiedzy w organizacji, PFPK, Warszawa

Okoń-Horodyńska E., 2000, Narodowy system innowacji w Polsce. W kierunku podejścia sieciowego, [w:] Proces dostosowania gospodarki polskiej do kryteriów członkowskich Unii Europejskiej, Wyd. AE, MWES w Tarnowie, Kraków-Tarnów

Pakulska T., 2005, Podatność innowacyjna Polski na napływ zagranicznego kapitału technologicznie intensywnego, SGH, Warszawa

Pocztowski A., 2006, Zarzqdzanie zasobami ludzkimi, Wyd. AE, Kraków

Porter M.E., 2001, Porter o konkurencji, PWE, Warszawa

Schumpeter J., 1960, Teoria rozwoju gospodarczego, PWN, Warszawa [1912 -wyd. w oryginale]

Senge P.M., 1998, Piqta dyscyplina. Teoria i praktyka organizacji uczacych się, Dom Wydawniczy ABC, Warszawa

Spencer L., Spencer S., 1993, Competence at Work: Models for Superior Performance, John Wiley \& Sons, New York

Stefanowicz B., 2007, Informacyjne systemy zarzadzania, SGH, Warszawa

Stiglitz J.E., 2004, Ekonomia sektora publicznego, PWN, Warszawa

Krzysztofek K., 2007, Wiek hiperkomunikacji, [w:] Wspótczesne procesy fragmentaryzacji i rekompozycji, Wyd. AE, Kraków

Tokarz A., 2005, Dynamika procesu twórczego, Wyd. UJ, Kraków

Wieluński A, 1998, Od industrializacji do reindustrializacji, Wyd. UW, Warszawa

Woźniak M.G., 2006, Rozwój sektora malych i średnich przedsiębiorstw w Polsce a wzrost gospodar$c z y$, Wyd. AE, Kraków.

Zioło Z., 2001, Wspótczesne tendencje rozwoju przemystu i ich problematyka badawcza, [w:] Problemy przemian struktur przestrzennych przemystu, Prace Komisji Geografii Przemysłu PTG, Warszawa-Kraków

Żuber R., Sankowska A., Gasik M., 2006, Najlepsze praktyki w zakresie organizacji działalności innowacyjnej w przedsiębiorstwie, „Zarządzanie Przedsiębiorstwem”, nr 1

\section{Infrastructure of innovative system as a factor of transformation of industrial structures}

It is proved in the article that identification and shaping of infrastructure of innovative system has contemporarily the fundamental meaning for transformation of industrial structures. Thus the pace of changes and effects of performed reindustrialization are determined by such infrastructure elements as: enterprise, competence, group activity and internal communication, organizational solutions together with computer support and network of external connections. This work is devoted to the characteristics of the mentioned elements. 